\title{
Evaluation of Bacteriocin Produced by Pediococcus pentosaceus Strain 2397 as Natural Preservative for Fish Meatballs Stored at Room Temperature
}

\author{
Usman Pato ${ }^{1 *}$, Yusmarini Yusuf ${ }^{1}$, Shanti Fitriani ${ }^{1}$, Diky Arma Fauzi ${ }^{1}$, Ghina \\ Ismadiah $^{1}$, Miftahul Hidayah ${ }^{1}$, Windy Sabiliani ${ }^{1}$ \\ ${ }^{I}$ Department of Agricultural Technology, Faculty of Agriculture, Universitas Riau \\ Kampus Bina Widya KM 12.5 Simpang Baru, Pekanbaru Indonesia \\ *Corresponding author. Email:usmanpato@yahoo.com
}

\begin{abstract}
Meatballs are one of the most popular processed meats in various countries. The meats commonly used to make meatballs are beef, chicken, and fish. The purpose of this study was to assess the quality of fish meatballs preserved with bacteriocin from Pediococcus pentosaceus strain 2397 during room temperature storage. The experimental design used in this study was a factorial, completely randomized design. There were two factors, i.e., bacteriocin concentrations $(0 \%, 0.15 \%, 0.30 \%, 0.45 \%$ and $0.60 \%)$ and storage time $(0,1,2$, and 3 days). Data obtained were statistically analyzed using Analysis of Variance and continued with Duncan Multiple Range Test at 5\% level. Meanwhile, data on microbiological counts were tabulated and analyzed descriptively. This study showed that the concentration of bacteriocins, storage time, and their interactions significantly affected fish meatballs' moisture and ash contents. The shelf life of fish meatballs at room temperature could be extended from 1 day in the treatment without bacteriocin to 2 days in the treatment using $0.60 \%$ bacteriocin with $73.21 \%$ water content, $0.93 \%$ ash, Staphylococcus aureus $0 \mathrm{CFU} / \mathrm{g}$, and TPC $2.60 \times 10^{5} \mathrm{CFU} / \mathrm{g}$. This finding is expected to be useful for preserving fish meatballs, especially for street meatball traders who do not have facilities for cooling and freezing the meatballs.
\end{abstract}

Keywords: Bacteriocin, Pediococcus pentosaceus, natural preservative, fish meatball, room temperature.

\section{INTRODUCTION}

Meatballs are one of the processed meats that are popular in various countries, including Indonesia. The meat commonly used to make meatballs is beef, pork, or chicken. Currently, meatballs are also made from fish meat [1]. The selection of fish meat must meet certain criteria; for example, the meat is white to produce fish balls of good quality and are liked by consumers [2]. One type of fish used as raw material for meatballs is catfish. Catfish is one of the leading fishery products in several countries because it has been successfully cultivated commercially. Catfish production in Indonesia reached 319,967 tons, and Riau Province was 23,190 tons [3]. Catfish contains high protein with a delicious and savory taste, so it is suitable to be processed into meatballs [4].
As a preservative, nitrite is commonly used in meatballs. Long-term exposure to $150 \mathrm{ppm}$ nitrite is hazardous to people's health since it can cause cancer [5]. Natural preservatives must be developed to reduce the number of chemical preservatives in processed foods. A natural preservative such as bacteriocin is referred to as a natural preservative in this scenario. Bio-preservation is the practice of employing LAB and its antimicrobial compounds, such as bacteriocin, to prevent harmful and spoilage bacteria from growing in food [6]. Bacteriocin is a peptide molecule made up of $12-100$ amino acids with amphiphilic properties and a cationic net charge generated and released to act extracellularly and kill bacteria [7]. These peptides are GRAS (generally recognized as safe) and continue to pique the curiosity of many scientists due to their future use in the pharmaceutical and food industries. Bacteriocin has long been used in the food sector to prevent food spoilage and 
foodborne illnesses [8]. These bacteriocins have various properties, including high stability, low toxicity, and a narrow to a broad spectrum of activity, making them ideal for use as natural food preservatives [9]. Bacteriocin produced by Pediococcus pentosaceus strain 2397 has a molecular weight of $14.4 \mathrm{kDa}$ and can inhibit several pathogenic bacteria such as Escherichia coli, Staphylococcus aureus, and Listeria monocytogenes [1012].

Bacteriocins are predicted to take the place of nitrite as a preservative in meatball manufacturing. This research aimed to evaluate the quality of fish meatballs preserved using bacteriocin from $P$. pentosaceus strain 2397 during storage at room temperature.

\section{MATERIALS AND METHOD}

\subsection{Raw Materials, Media, Chemicals}

The main raw material used to make meatballs was catfish (Pangasianodon hypophthalmus). Other ingredients used were tapioca flour, shallots, garlic, table salt, pepper, water, and ice block. All raw materials and ingredients for making fish meatballs were purchased at the local market in Pekanbaru, Indonesia. The media used to activate Pediococcus pentosaceus strain 2397 isolated from dadih from Bukittinggi, West Sumatera, Indonesia, was MRS Broth (Merck), and media for microbiological analysis, PCA (Merck) and Baird Parker Agar (Himedia). The chemicals used include ammonium sulfate, phosphate buffers, and other chemicals for proximate analysis.

\subsection{Activation of Pediococcus pentosaceus Strain 2397}

The activation of $P$. pentosaceus strain 2397 was carried out according to the method described in our previous work [10]. Each LAB culture was taken as much as $0.1 \mathrm{~mL}$ and put into a test tube containing $5 \mathrm{~mL} \mathrm{MRSB}$, then shaken evenly and incubated aerobically for $18 \mathrm{~h}$ at $37^{\circ} \mathrm{C}$.

\subsection{Production of Bacteriocin}

$P$. pentosaceus strain 2397 was propagated in MRSB by adding inoculum $2.5 \%$ of the active culture and incubation at $37^{\circ} \mathrm{C}$ for $24 \mathrm{~h}$. Then, the whole broth was centrifuged at $10,000 \mathrm{rpm}$ for $15 \mathrm{~min}$ to get the supernatant. Previously, the antibacterial activity of strain 2397's supernatant was demonstrated to be effective in inhibiting the growth of E. coli, S. aureus, and $L$. monocytogenes $[10,11,12]$. The supernatant separated from the cells was then added with $70 \%$ ammonium sulfate and put in the refrigerator $\left(4^{\circ} \mathrm{C}\right)$ for 12 $\mathrm{h}$ to precipitate the protein. This mixture was centrifuged at $10,000 \mathrm{rpm}$ at $4^{\circ} \mathrm{C}$ for $30 \mathrm{~min}$ to obtain crude bacteriocin [13].

\subsection{Preparation of Fish Meatballs}

Fish meatballs were prepared according to the method by Sinaga et al. [14]. Catfish were made into fillets and soaked in cold water with a ratio of meat and water 1:3 $(\mathrm{w} / \mathrm{v})$ at $5^{\circ} \mathrm{C}$ for 40 minutes. Furthermore, the fillet of catfish is trimmed to reduce fat using a knife. The fillet of catfish meat after trimming is crushed using a grinder until the meat becomes pulverized. Fish meat is mixed with spices (pepper, garlic, sugar, and salt $2 \%$ each) of the weight of the meat into the dough to be blended again. Furthermore, $200 \mathrm{~g}$ of catfish added little by little tapioca flour $50 \mathrm{~g}$ while stirring and pulverized until a homogeneous dough is obtained. Furthermore, the fishball dough was given bacteriocin according to the treatment, namely 0 (control), $0.15 ; 0.30 ; 0.40$, and $0.60 \%(w / w)$ of the amount of meatball dough. The dough was made of meatballs with a diameter of about $2.5 \mathrm{~cm}$. The meatballs were heated in boiling water for 10-15 minutes until the meatballs float. The meatball samples were then packed aerobically in polyethylene bags and stored at room temperature (about $28-30^{\circ} \mathrm{C}$ ) and taken for physical and microbiological analysis every day $(0,1,2$, and 3 days).

\subsection{Chemical and Microbiological Analysis}

The parameters observed were chemical analysis, including water and ash contents using gravimetric technique [15], and microbiological analysis, including Total Plate Count and the number of $S$. aureus using the surface dish method [16].

\subsection{Data Analysis}

Chemical content data were statistically analyzed using Analysis of Variance and continued with Duncan Multiple Range Test (DMRT) at 5\% level using SPSS Software Version 23. Meanwhile, data on microbiological counts were tabulated and analyzed descriptively.

\section{RESULT AND DISCUSSION}

Moisture content is one of the most critical factors that affect the texture, flavor, stability, and shelf life of food [17]. The analysis of variance showed that the concentration of bacteriocins, storage time, and their interactions significantly affected the moisture content of fish meatballs. The average moisture content of fish meatballs after DMRT at the 5\% level is presented in Table 1. 
Table 1 The moisture content of fish meatballs added various concentrations of bacteriocin during storage at room temperature

\begin{tabular}{|c|c|c|c|c|c|}
\hline \multirow[t]{2}{*}{$\begin{array}{l}\text { Concent } \\
\text { ration of } \\
\text { bacterio } \\
\text { cin }\end{array}$} & \multicolumn{5}{|c|}{ Moisture content (\%) at } \\
\hline & Day 0 & Day 1 & Day 2 & Day 3 & $\begin{array}{l}\text { Ave } \\
\text { rage }\end{array}$ \\
\hline $0 \%$ & $72.84^{\mathrm{a}, \mathrm{b}, \mathrm{c}}$ & $72.92^{\mathrm{a}, \mathrm{b}, \mathrm{c}}$ & $72.63^{\mathrm{a}, \mathrm{b}, \mathrm{c}, \mathrm{d}}$ & $73.85^{\mathrm{a}}$ & $73.06^{\mathrm{a}}$ \\
\hline $0,15 \%$ & $69.66^{\mathrm{f}, \mathrm{g}}$ & $70.10^{\mathrm{f}, \mathrm{g}}$ & $70.22^{\mathrm{f}, \mathrm{g}}$ & $70.54^{\mathrm{f}, \mathrm{g}}$ & $70.13^{d}$ \\
\hline $0,30 \%$ & $70.64^{\mathrm{e}, \mathrm{f}, \mathrm{g}}$ & $70.93^{e, f, g}$ & $71.56^{\mathrm{c}, \mathrm{d}, \mathrm{e}, \mathrm{f}}$ & $72.79^{a, b, c}$ & $71.48^{c}$ \\
\hline $0,45 \%$ & $71.24^{\mathrm{d}, \mathrm{e}, \mathrm{f}}$ & $72.12^{\mathrm{b}, \mathrm{c}, \mathrm{d}, \mathrm{e}}$ & $72.48^{\mathrm{a}, \mathrm{b}, \mathrm{c}, \mathrm{d}}$ & $72.93^{\mathrm{a}, \mathrm{b}, \mathrm{c}}$ & $72.19^{b}$ \\
\hline $0,60 \%$ & $72.81^{\mathrm{a}, \mathrm{b}, \mathrm{c}}$ & $73.11^{\mathrm{a}, \mathrm{b}, \mathrm{c}}$ & $73.21^{\mathrm{a}, \mathrm{b}}$ & $73.21^{\mathrm{a}, \mathrm{b}}$ & $73.08^{a}$ \\
\hline Average & $71.44^{b}$ & $71.84^{b}$ & $72.02^{b}$ & $72.66^{a}$ & \\
\hline
\end{tabular}

Means followed by the lowercase letters indicate a significant difference $(\mathrm{P}<0.05)$.

The data in Table 1 shows that the higher the concentration of bacteriocin used, the higher the moisture content of fish balls. Bacteriocin from strain 2397 is a low-molecular-weight peptide having a molecular mass of $14.4 \mathrm{kDa}$ [12]. Hydrophilic peptides and proteins have a high water-holding capacity, preventing water from leaving their three-dimensional structure during processing [18]. The greater the increase in water absorption in the fish meatballs formed, the higher the protein content. The treatment without bacteriocin addition, on the other hand, had a high moisture content as well. This finding is because the number of microorganisms in this treatment was higher than in the other treatments (Figure 1). These bacteria break down protein, carbohydrate, and fat in meatballs to generate water, increasing the moisture content of fish meatballs.

Table 1 clearly illustrates that the higher the moisture content, the longer the storage time, especially on the third day of room temperature storage. This fact is most likely due to fish meatballs accumulating water while being stored at a temperature that accounts for the relative humidity of the air at the study site (Pekanbaru, Indonesia). The higher the relative humidity, the more water the food contains [19]. Furthermore, the longer the fish meatballs were stored, the more microorganisms proliferated (Figure 1) and broke down the chemical components, causing the moisture content to rise, especially on the third day of storage.

The moisture content of fish balls in this study varied from 69.66 to $73.85 \%$, which is still lower than the 74.45$76.01 \%$ reported by Farareza [20]. The high moisture content in Farareza's study was most likely due to the use of sago flour as extra raw material in the production of fish balls, whereas tapioca was employed in our investigation. In this study, the addition of $0.15 \%$ bacteriocin during storage at room temperature met the criteria of the Indonesian National Standard (SNI 7266:2017) on fish balls, which states that the maximum water content is $70 \%$. Other treatments, with a range of $71.24-73.85 \%$, slightly exceeded the existing requirements.

Ash is an inorganic residue that results from the combustion of various minerals at high temperatures to produce ash, with varied compositions depending on the type and source of food consumed [21]. The analysis of variance showed that the concentration of bacteriocins, storage time, and their interactions significantly influenced the ash content of fish meatballs. Table 2 shows the average ash content of fish meatballs after DMRT at a 5\% level. Table 2 reveals that the greater the bacteriocin concentration applied, the lower the ash level in fish meatballs. Bacteriocins are peptides made up of amino acids and do not contain minerals. As a result, the more bacteriocins were used, the lower the ash content in the fish meatballs. The data in this table also shows that the longer the fish meatballs were stored, the less ash they contain. This fact is because the longer the storage, the more bacteria grew and utilized certain minerals. Microminerals have been discovered to have a variety of biological roles in microbes. For example, potassium ions $\left(\mathrm{K}^{+}\right)$are involved in the action of various enzymes, calcium $\left(\mathrm{Ca}^{2+}\right)$ is a key component of bacterial endospores, and magnesium $\left(\mathrm{Mg}^{2+}\right)$ is used as a cofactor in a variety of enzymes.

Table 2 Ash content of fish meatballs added various concentrations of bacteriocin during storage at room temperature

\begin{tabular}{llllll}
\hline $\begin{array}{l}\text { Concentra } \\
\text { tion of } \\
\text { bacterioci } \\
\mathrm{n}\end{array}$ & \multicolumn{5}{c}{ Ash content $(\%)$ at } \\
\cline { 2 - 6 } & Day 0 & Day 1 & Day 2 & Day 3 & $\begin{array}{c}\text { Ave } \\
\text { rage }\end{array}$ \\
\cline { 2 - 6 } $0 \%$ & $1.32^{\mathrm{a}, \mathrm{b}, \mathrm{c}, \mathrm{d}}$ & $1.13^{\mathrm{f}}$ & $1.13^{\mathrm{f}}$ & $1.14^{\mathrm{f}}$ & $\mathbf{1 . 1 8}^{\mathbf{c}}$ \\
$0,15 \%$ & $1.22^{\mathrm{c}, \mathrm{d}, \mathrm{e}, \mathrm{f}}$ & $1.35^{\mathrm{a}, \mathrm{b}, \mathrm{c}}$ & $1.38^{\mathrm{a}}$ & $1.19^{\mathrm{d}, \mathrm{e}, \mathrm{f}}$ & $\mathbf{1 . 2 8}^{\mathbf{a}}$ \\
$0,30 \%$ & $1.22^{\mathrm{c}, \mathrm{d}, \mathrm{e}, \mathrm{f}}$ & $1.31^{\mathrm{a}, \mathrm{b}, \mathrm{c},}$ & $1.37^{\mathrm{a}, \mathrm{b}}$ & $1.09^{\mathrm{f}}$ & $\mathbf{1 . 2 5}^{\mathrm{a}, \mathbf{b}}$ \\
$0,45 \%$ & $1.31^{\mathrm{a}, \mathrm{b}, \mathrm{c}, \mathrm{d}}$ & $1.21^{\mathrm{c}, \mathrm{d}, \mathrm{e}, \mathrm{f}}$ & $1.31^{\mathrm{a}, \mathrm{b}, \mathrm{c}, \mathrm{d}, \mathrm{e}}$ & $0.94^{\mathrm{g}}$ & $\mathbf{1 . 1 9}^{\mathbf{b}, \mathbf{c}}$ \\
$0,60 \%$ & $1.16^{\mathrm{e}, \mathrm{f}}$ & $1.14^{\mathrm{f}}$ & $1.23^{\mathrm{b}, \mathrm{c}, \mathrm{d}, \mathrm{e}, \mathrm{f}}$ & $0.93^{\mathrm{g}}$ & $\mathbf{1 . 1 2}^{\mathbf{d}}$ \\
\hline Average & $\mathbf{1 . 2 5}^{\mathrm{a}}$ & $\mathbf{1 . 2 3}^{\mathrm{a}}$ & $\mathbf{1 . 2 8}^{\mathrm{a}}$ & $\mathbf{1 . 0 6}^{\mathbf{b}}$ & \\
\hline
\end{tabular}

Microminerals, on the other hand, such as manganese, zinc, cobalt, molybdenum, nickel, and copper, play a variety of roles in biological functioning. Zinc $\left(\mathrm{Zn}^{2+}\right)$ is found at the active site of numerous enzymes, manganese $\left(\mathrm{Mn}^{2+}\right)$ is involved in phosphate group transfer catalysis, and molybdenum $\left(\mathrm{Mo}^{2+}\right)$ is required for nitrogen fixation [22]. 
The ash content in this study ranged from 0.93 to $1.32 \%$. The ash content of this study was lower with the findings of Farareza [20], who reported that the ash content in fish balls ranged from 1.68-1.83\%. Although both use catfish to make meatballs, this difference may be due to differences in the amount and type of additional raw materials such as salt and spices.

The pathogenic bacteria Staphylococcus aureus infects humans and animals, causing various clinical symptoms such as infection of the superficial skin and soft tissue, sepsis, pneumonia, and endocarditis [23]. The number of $S$. aureus in fish meatballs is presented in Table 3

Table 3 Number of Staphylococcus aureus of fish meatballs added various concentrations of bacteriocin during storage at room temperature

\begin{tabular}{|c|c|c|c|c|c|}
\hline \multirow[t]{2}{*}{$\begin{array}{l}\text { Concentr } \\
\text { ation of } \\
\text { bacterioc } \\
\text { in }\end{array}$} & \multicolumn{5}{|c|}{ Number of $S$. aureus (CFU/g) at } \\
\hline & Day 0 & Day 1 & Day 2 & $\begin{array}{c}\text { Day } \\
3\end{array}$ & $\begin{array}{l}\text { Ave } \\
\text { rage }\end{array}$ \\
\hline $0 \%$ & 0 & 0 & 0 & 0 & 0 \\
\hline $0,15 \%$ & 0 & 0 & 0 & 0 & 0 \\
\hline $0,30 \%$ & 0 & 0 & 0 & 0 & 0 \\
\hline $0,45 \%$ & 0 & 0 & 0 & 0 & 0 \\
\hline $0,60 \%$ & 0 & 0 & 0 & 0 & 0 \\
\hline Average & 0 & 0 & 0 & 0 & \\
\hline
\end{tabular}

In vitro test results showed that bacteriocin from $P$. pentosaceus strain 2397 inhibited the growth of $S$. aureus [12]. However, looking at the number of $S$. aureus that produced $0 \mathrm{CFU} / \mathrm{g}$ in fish balls without the addition of bacteriocin, it can be ascertained that it was not bacteriocin that inhibited the growth of $S$. aureus. The main factor causing the non-growth of $S$. aureus in all treatments of fish meatball samples was probably due to good sanitation and hygiene practices during the manufacture of fish meatballs. In the food sector, contaminated surfaces aid in the transfer of dangerous pathogens. The spread of pathogenic microbes like $S$. aureus in the food business and restaurants is mostly due to the hands of food workers [24]. Hand hygiene, washing, and disinfection are prerequisites for hygiene management in the food sector to reduce the risk of foodborne diseases [25]. The number of $S$. aureus in the study has met the quality standard of fish meatballs of a maximum of $10^{2} \mathrm{CFU} / \mathrm{g}$.

The total plate number (TPC) is one method of calculating the number of microbial colonies, both bacteria and fungi, contained in meatball samples. The calculation of the number of bacteria was carried out using the total plate count method. Microorganisms that are still alive are grown on an agar medium to multiply and form colonies that can be seen and counted directly [26]. The average TPC in fish meatballs is presented in Figure 1.

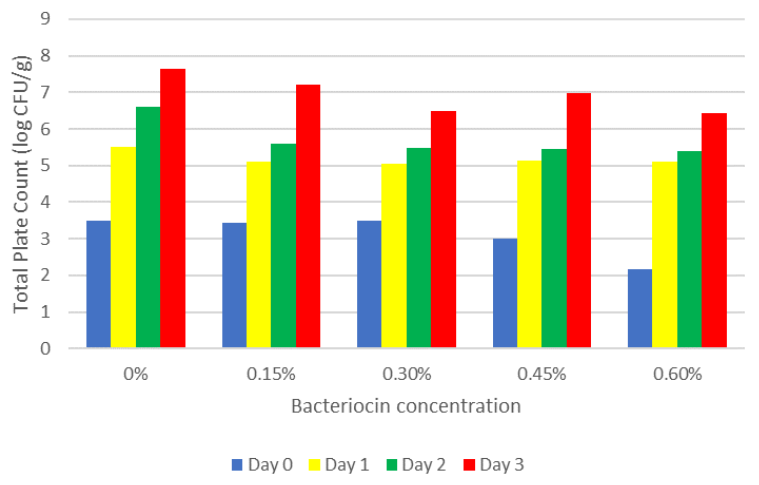

Figure 1 Total Plate Count of fish meatballs added various concentrations of bacteriocin during storage at room temperature

The data in Figure 1 shows that the higher the concentration of bacteriocin used, the smaller the TPC value. This fact is due to the more available bacteriocin in the meatball matrix to inhibit microbial growth. In in vitro studies, bacteriocins resulting from $P$. pentosaceus strain 2397 could inhibit the growth of E. coli, S. aureus, and L. monocytogenes $[10,11,12]$. Because it was able to inhibit pathogenic bacteria, it is suspected that this bacteriocin can also inhibit microbes that cause damage to fish meatballs. Thus, the more bacteriocins used, the less TPC in fish meatballs. Figure 1 also shows that the longer the storage time at room temperature, the higher the TPC value in fish meatballs. This phenomenon was due to the accumulation of microbes that grow in fish meatballs over storage time at room temperature.

The TPC value of fish balls without the addition of bacteriocin on day 2 was $6.61 \log \mathrm{CFU} / \mathrm{g}$ or $4.03 \times 10^{6}$ $\mathrm{CFU} / \mathrm{g}$. Based on the TPC value on the quality standard of fish meatballs (SNI 7266:2017), $10^{6} \mathrm{CFU} / \mathrm{g}$ based on three-class sampling, the fish meatballs product without bacteriocin addition starting from day 2 has been microbiologically rejected and is no longer suitable for consumption or marketing. On the other hand, meatballs treated with bacteriocin preservative at various concentrations had a TPC of $2.60 \times 10^{5}$ to $4.03 \times 10^{5}$ $\mathrm{CFU} / \mathrm{g}$. This finding means that the fish balls that were given bacteriocin as a preservative still met the quality standards of the fish balls until the second day. However, on the 3rd day, the meatballs given various concentrations of bacteriocin had a TPC of more than $3.00 \times 10^{6} \mathrm{CFU} / \mathrm{g}$, so that these meatballs did not meet the quality standard. The results of this study indicate that bacteriocin could extend the shelf life of fish meatballs by one day longer than the control (not treated with bacteriocin) when stored at room temperature. 


\section{CONCLUSION}

It can be concluded that the concentration of bacteriocins, storage time, and their interactions significantly influenced the moisture and ash contents of fish meatballs. S. aureus was not found in all samples of fish meatballs in all treatments, which indicated the good application of sanitation and hygiene practices during the processing of fish meatballs. TPC on days 0 and 1 had the number that still met the quality standards of meatballs in all treatments. However, on day 2, TPC in the treatment without bacteriocin had exceeded the amount specified in the quality standard of fish meatballs. On day 3, all treatments had a TPC that had exceeded the fish meatball quality standard, which was a maximum of $10^{5} \mathrm{CFU} / \mathrm{g}$. The shelf life of fish meatballs at room temperature can be extended from 1 day in the treatment without the use of bacteriocin to 2 days in the treatment using $0.60 \%$ bacteriocin with $73.21 \%$ water content, $0.93 \%$ ash, Staphylococcus aureus $0 \mathrm{CFU} / \mathrm{g}$, and TPC $2.60 \times 10^{5}$ $\mathrm{CFU} / \mathrm{g}$.

\section{ACKNOWLEDGMENTS}

The research was financed by Contract Number: 051/E4.1/AK.04.PT/2021 from the Directorate of Resources, Director General of Higher Education, Ministry of Education, Culture, Research and Technology of the Republic of Indonesia.

\section{REFERENCES}

[1] M.K. Morsy, M. Enas, R. Elsabagh. Impact of pomegranate peel nanoparticles on quality attributes of meatballs during refrigerated storage. LWT-Food Science and Technology. 2017, pp. 133.

[2] A. Fauziyah. 2019. The effect of the amount of sago flour (Metroxylon sago Rottb) and the amount of spinach (Amaranthus spp) on the organoleptic properties of spinach cork fish meatballs. E-Journal Boga, vol. 5(3), 2019, pp. 1-10.

[3] Indonesian Central Statistics Agency. Production of catfish in Indonesia and Riau. 2021. https://www.bps.go.id

[4] A. Rahardianto, Abdulgani, Nurlita, N. Trisyani. Effect of concentration of the honey solution in physiological $\mathrm{NaCl}$ on viability and mobility of catfish (Pangasius pangasius) spermatozoa during storage. Jurnal Sains dan Seni, ITS. vol. 1(1), 2012, pp. 2301-928X.

[5] World Health Organization. Nitrate and Nitrite in Drinking-water. WHO Press, World Health Organization, 20 Avenue Appia, 1211 Geneva 27, Switzerland. 2011.

[6] M.E. Stiles. Biopreservation by lactic acid bacteria. In Antonie van Leeuwenhoek. International Journal of General and Molecular Microbiology, vol. 70(2-4), 1996, pp. 331-345.

[7] A.C. Rios, C.G. Moutinho, F.C. Pinto, F.S. Del Fiol, A. Jozala, M.V. Chaud, M.M.D.C.Vila, J.A. Teixeira, V.M. Balcão, Alternatives to overcoming bacterial resistances: State-of-the-art. Microbiological Research. Vol. 191, 2016, pp. 5180. http://dx.doi.org/10.1016/j. micres.2016.04.008. PMid:27524653.

[8] R.H. Perez, T. Zendo, K. Sonomoto. Novel bacteriocins from lactic acid bacteria (LAB): Various structures and applications. Microbial Cell Factories, 13(Suppl 1), 2014, S1-S3. http://dx.doi.org/10.1186/1475- 2859-13-S1-S3. PMid:25186038.

[9] V. Bharti, A. Mehta, S. Singh, N. Jain, L. Ahirwal, S. Mehta. Bacteriocin: a novel approach for preservation of food. International Journal of Pharmacy and Pharmaceutical Sciences. Vol. 7(9), 2015, pp. 20-29.

[10] U. Pato, Y. Yusmarini, S Fitriani, N.N Jonnaidi, M.S Wahyuni, J.A Feruni, I. Jaswir. Inhibitory activity of crude bacteriocin produced by lactic acid bacteria isolated from dadih against Listeria monocytogenes. Biodiversitas. vol. 21(4), 2020, pp. 1295-1302.

[11] U. Pato, Y. Yusmarini, S. Fitriani, N.N Jonnaidi, M.S Wahyuni, J.A Feruni and I Jaswir. Antimicrobial Activity of Lactic Acid Bacteria Strains Isolated from Dadih against Escherichia coli. IOP Conf. Series: Earth and Environmental Science 709 (2021) 012019. 2021a.

[12] U. Pato, E. Riftyan, D.F. Ayu, N.N. Jonnaidi, M.S. Wahyuni, J.A. Feruni, M.A. Abdel-Wahhab. Antibacterial efficacy of lactic acid bacteria and bacteriocin isolated from Dadih's against Staphylococcus aureus. Food Science and Technology Campinas, Ahead of Print, 2021b.

[13] N.R. Sankar, V.D. Priyanka, P.S. Reddy, P. Rajanikanth, V.K. Kumar, M. Indira. Purification and Characterization of Bacteriocin Produced by Lactobacillus Plantarum Isolated from Cow Milk. International Journal of Microbiological Research, vol. 3(2), 2012, pp. 133-137.

[14] D.D. Sinaga, Herpandi, R. Nopianti.. Characteristics of catfish meatballs (Pangasius pangasius) with the addition of carrageenan, soy protein isolate, and sodium tripolyphosphate. Jurnal Teknologi Hasil Perikanan. vol. 6(1), 2017, pp. 1-13.

[15] AOAC. Official methods of analysis, 16th eds. Association of Official Analytical Chemists, Washington. 1999.

[16] AOAC. Official Methods of Analysis of AOAC International. 18th ed. Assoc. Off. Anal. Chem., Arlington. 2005.

[17] S. Sumathi. Food Chemistry and Nutrition: A Comprehensive Treatise. BSP Books Pvt. Ltd. 2014.

[18] Y.U. Putri. Study on the production of winged beans (P. tetragonolubus L. DC) using the wet- 
milling method and analysis of physicochemical properties and functional characteristics. Thesis. Bogor Agricultural University. Bogor. 2010.

[19] F. Kong, R.P. Singh. 2 - Chemical Deterioration and Physical Instability of Foods and Beverages. The Stability and Self Life of Food. Second Edition. Woodhead Publishing. 2016.

[20] J.R. Farareza. Physical, chemical and organoleptic characteristics of catfish meatballs (Pangasius pangasius) with sago flour substitution. Thesis. Brawijaya University, Malang, Indonesia. 2018.

[21] N. Andarwulan, F. Kusnandar, D. Herawati. Food Analysis. PT. Dian Rakyat. Jakarta. 2011.

[22] W. Weisany, Y. Raei, K. H. Allahverdipoor. Role of Some of Mineral Nutrients in Biological Nitrogen Fixation. Bulletin of Environment, Pharmacology and Life Sciences, Vol 2 (4), 2013, pp. 77-84

[23] J.M. Willey, L.M. Sherwood, C.J. Woolverton. Prescott, Harley and Klein's Microbiology. $7^{\text {th }}$ Edition. New York: McGraw-Hill Higher Education. 2008.

[24] S.Y.C. Tong, J.S. Davis, E. Eichenberger, T.L. Holland, V.G.Jr. Fowler. Staphylococcus aureus infections: Epidemiology, pathophysiology, clinical manifestations, and management. Clinical Microbiology Reviews, vol. 28(3), 2015, pp. 603661. http://dx.doi.org/10.1128/ CMR.00134-14. PMid:26016486.

[25] J. Kadariya, T.C. Smith, D. Thapaliya. Staphylococcus aureus and Staphylococcal FoodBorne Disease: An Ongoing Challenge in Public Health. BioMed research International,vol. 2014, 2014, pp. 1-9.

[26] World Health Organization. Improved hand hygiene to prevent healthcare-associated infections. Patient Safety Solutions 2007;1 (Solution 9). Available: http://www.who.int/patientsafety/solutions/patient safety/PS-Solution9.pdf. Accessed 25 August 2015.

[27] N.G. Nasution, T.R. Ferasyi, Razali, Erina, Nazaruddin, A. Harris. Examination of formalin and microbial contamination in meatballs sold in several places in Langsa City. Jurnal JIMVET. vol. 2(3), 2018, pp. 288-295. 